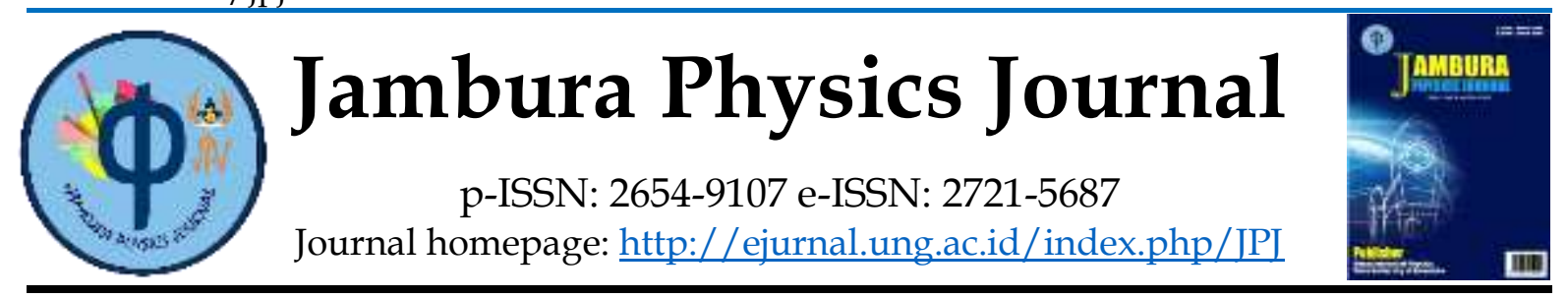

\title{
DEVELOPMENT OF MECHANICAL ENERGY TEACHING AIDS BASED ON ARDUINO UNO MICROCONTROLLER ASSISTED ULTRASONIC SENSORS AND LOAD CELLS
}

\author{
Matsun ${ }^{1}$, Boisandi 1* , Ira Nofita Sari ${ }^{1}$, Soka Hadiati ${ }^{1}$, Deden Hidayat ${ }^{1}$ \\ ${ }^{1}$ IKIP PGRI Pontianak, Jalan Ampera No. 88. Pontianak, Kalimantan Barat, 78116, Indonesia \\ *Email: bsandi2021@gmail.com
}

Received: 20 September 2021. Accepted: 25 October 2021. Published: 30 October 2021

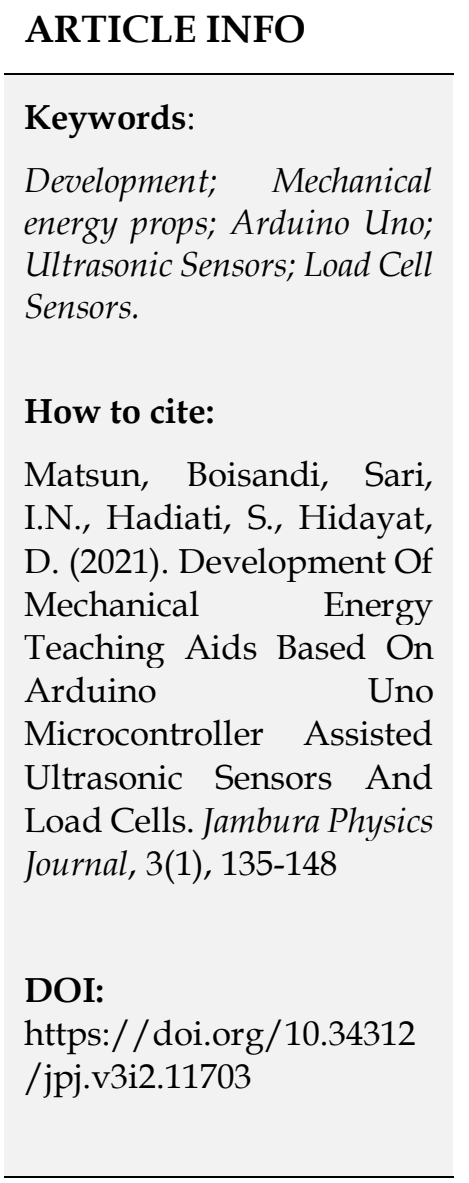

\begin{abstract}
The study aims to produce a mechanical energy prop by worthy using an Arduino Uno microcontroller assisted by an ultrasonic sensor and a load cell. The research method uses research and development design according to the ADDIE model which consists of 5 stages by analysis, design, development, implementation, and evaluation. The feasibility of mechanical energy props is determined according to experts. The research was carried out in 2021, a limited trial was carried out on students at SMA Negeri 3 Sungai Kakap. Research subjects' responses to the props are also known to use response questionnaires. The validation results of mechanical energy props based on the Arduino Uno microcontroller by two media experts obtained an average score of $95 \%$ in the excellent category and by two material expert validators, an average percentage of $97.21 \%$ was obtained in the excellent category. The response of research subjects to mechanical energy teaching aids based on the Arduino Uno microcontroller obtained an average score of $87.72 \%$ with an excellent category. Overall, mechanical energy teaching aids based on the Arduino Uno microcontroller assisted by an ultrasonic sensor and a load cell have been produced.
\end{abstract}

\section{Introduction}

Creativity and innovation in the physics learning process are very important to apply because it is one to efforts so that students get updated basic scientific aspects 
to recognize the symptoms of physics in everyday life. The understanding of learning that is carried out, is not only limited to learning, but also the practice that is needed directly as part of an effort to increase students' understanding more deeply. Physics as a science is not only the mastery of a collection of knowledge in the form of facts, concepts, or principles but also an experimental process. Education must be present competencies indirect experience to develop students who can understand what is being studied. In practice, physics learning needs to be done seriously and consistently so that the experience gained is more real and meaningful, but the learning must still be attractive and fun and not rigid for students (Alarifin, 2014).

One effort to create an interesting and fun physics learning atmosphere is that educators as facilitators can use learning media in the form of teaching aids (Wahyuningsih et al., 2019). The use of learning media in the form of teaching aids is highly recommended because by utilizing appropriate teaching aids, physics learning will be more effective by directly demonstrating and conducting experiments. In addition, by using teaching aids, learning physics, which is considered by students as a complicated subject, will become more effective and fun in learning (Anas, 2014). The use of teaching media in the form of teaching aids in the learning process can trigger new desires and interests and can motivate learning (Aminulloh \& Widodo, 2018; Pambudi \& Bayu, 2018). Therefore, the existence of teaching aids as a supporting media in the learning process is considered necessary and very important to be able to grow and develop.

Observations to show that the use of learning media in the form of teaching aids is not carried out due to the limitations of teaching aids in the laboratory. The study also found a lack of knowledge updates related to current technological developments, such as props based on control technology. Technological advances in the current era of the industrial revolution 4.0 have brought changes to learning tools that work manually starting to be developed with digital techniques such as digital scales, digital stopwatches, digital multimeters, and more.

These changes are made to facilitate data reading and minimize data reading errors caused by human error. In this study, the application of technological advances in the era of the industrial revolution 4.0 is the use of the Arduino Uno microcontroller as a technology-based tool that can be integrated with one control system, especially in the use of digital technology. Arduino is one of the newest types of controller components from the microcontroller family with a programming language using the C language. With the help of Arduino libraries, it can be used to develop interactive systems that accept input from various sensors or switches by controlling the work of the tool according to the wishes of the maker. Another advantage that Arduino has is low power, so its use is suitable for use as a control system in the manufacture of physics teaching aids (Nurjanah, 2017).

Referring to the findings of the problems obtained from the interviews, the researchers will develop physics learning media in the form of teaching aids that could be integrated into a single control system. The teaching aids that will be developed are based on the use of the sensor-assisted Arduino Uno microcontroller. The topic of discussion that will be used by researchers as a theoretical study and guide to the development of teaching aids is mechanical energy. 
Matsun, et.al / Jambura Physics Journal (2021) Vol. 3(2): 135-148

The Arduino Uno microcontroller-based teaching aid that will be developed is a teaching aid that will explain the basic concepts of mechanical energy practically and visually to prove the theoretical basis of the material. Researchers use Arduino as a teaching aid microcontroller because Arduino is a microcontroller whose programming language is quite easy to understand (Syahwil, 2013). Initialization of sensors into Arduino is also easy to implement because it does not use a complicated programming language. The use of physics learning teaching aids based on the Arduino Uno microcontroller is more directed to the use of tools with control systems that work automatically according to the command language of the program being run. The utilization of Arduino as a control system on teaching aids can also facilitate the reading of measurement results and minimize manual measurement reading errors caused by human error in the mechanical energy props used.

The development of Arduino Uno-based teaching aids has a major contribution in creating a digital technology-based learning aid performance (Saputri et al., 2017). The research conducted has not studied the basic concepts of mechanical energy in a more complex manner. The research shows that the amount of mechanical energy is generated from the sum of the potential and kinetic energy of an object but has not shown that the relationship between potential energy and kinetic energy when the object's maximum and minimum height influences the value of the mechanical energy produced. Base on the explanation of the problems that have been explained, the researchers are interested in researching the development of mechanical energy teaching aids based on Arduino Uno microcontroller-assisted ultrasonic sensors and load cells.

\section{Methode}

The method in this research plan is the research and development method (Sugiyono, 2016). The research model in this study is the ADDIE model which consists of 5 stages: analysis, design, developt, Implementation, and Evaluation. The use of the ADDIE model in this study is suitable to be applied because the basis of the application of the model is oriented to the development of learning strategies and learning media. In addition, the application of the ADDIE model is used for constructional development, namely getting updates from the products developed (Perbadi, 2015). In this study, the researcher limited the research to the Development stage due to limited manpower, time and cost so that the researcher was only limited to testing the feasibility level of the product or props made based on validation by media, material, and student responses without disseminating the product.

The subject of development in this study is a validator consisting of media and material experts, each of whom is tasked with validating the products used in this study. the validator will assess whether the product development of teaching aids is made as an alternative to physics learning aids on the concept of mechanical energy. The media validator in this study consisted of two lecturers from the Physics Education Study IKIP PGRI Pontianak. The program was experts in assessing the feasibility of the media. The material validators consist of two lecturers from the Physics Education IKIP PGRI Pontianak who are experts in assessing the feasibility of 


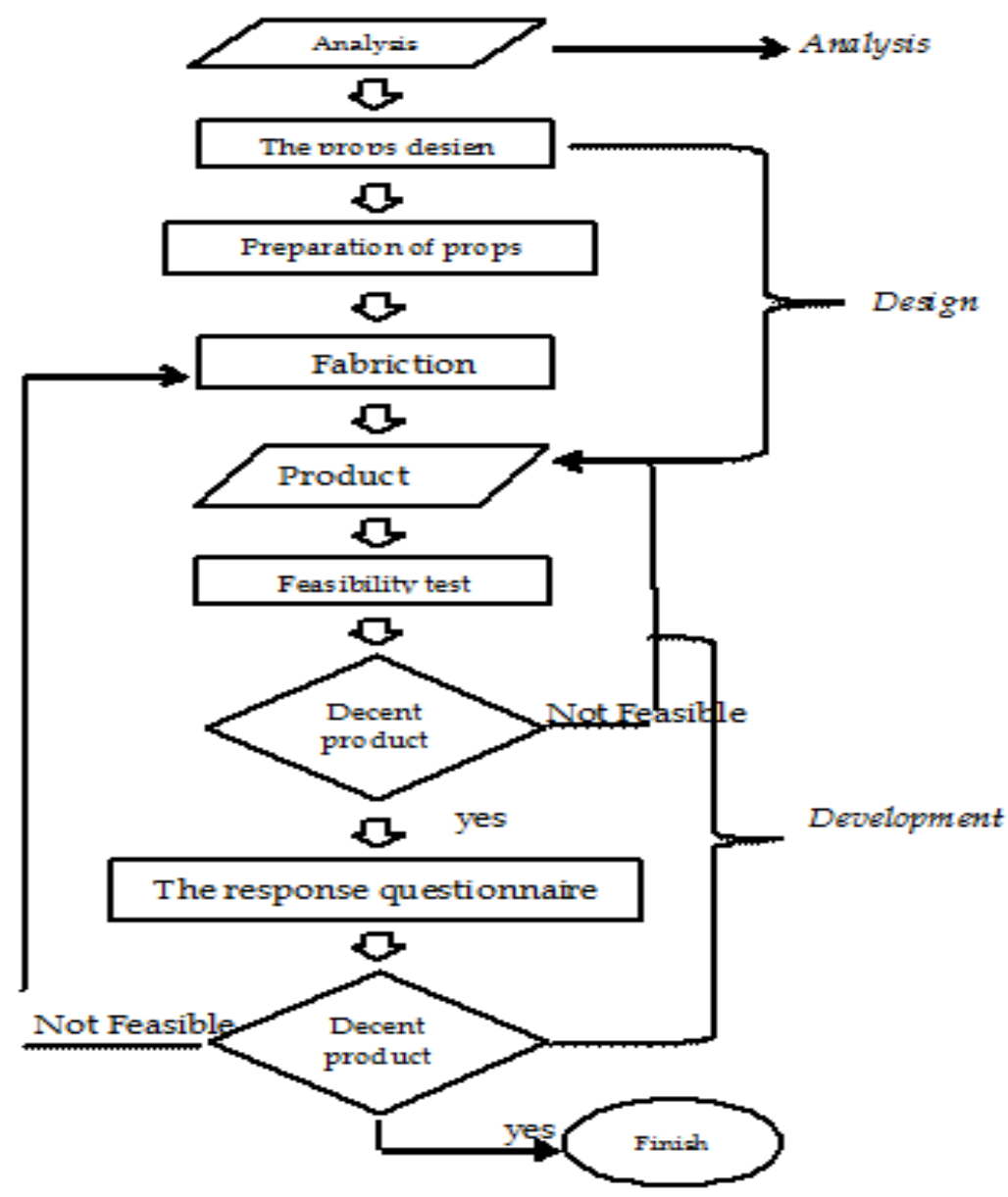

Figure 1. Research flow diagram

the material. The product trial subject is aimed at 10th-grade students SMA Negeri 3 Sungai Kakap. The class used in the study was the 10th class of science at SMA Negeri 3 Sungai Kakap as a sample of the trial plan for the research product being developed.

The following are the stages of the flow used in this research as described in the flowchart Figure 1. Figure 1 describes the stages of the flow in the research, which uses the ADDIE research model, but in practice, not all stages are carried out due to limited manpower, time and cost so that researchers are only limited to testing the feasibility level of the product.

The research design will be divided into two, namely hardware design which consists of electronic circuit design, the second is software design. The electronic circuit design can be seen in Figure 2. Figure 2 illustrates the electronic circuit system that will be made. From the diagram, when the load cell sensor detects the weight of the object and the ultrasonic sensor detects the height of the object when it falls, the measurement results will be input into the Arduino Uno system to then be processed into output data to be displayed on the LCD. To start the program system, a pushbutton is provided which functions to input the time of the object. When all measurement variables are inputted into the Arduino Uno system, these variables will be processed by the Arduino Uno programming language IC data to find the value of the mechanical energy produced. The results of the mechanical energy measurement will be displayed on the LCD. Software design has a close relationship with the 


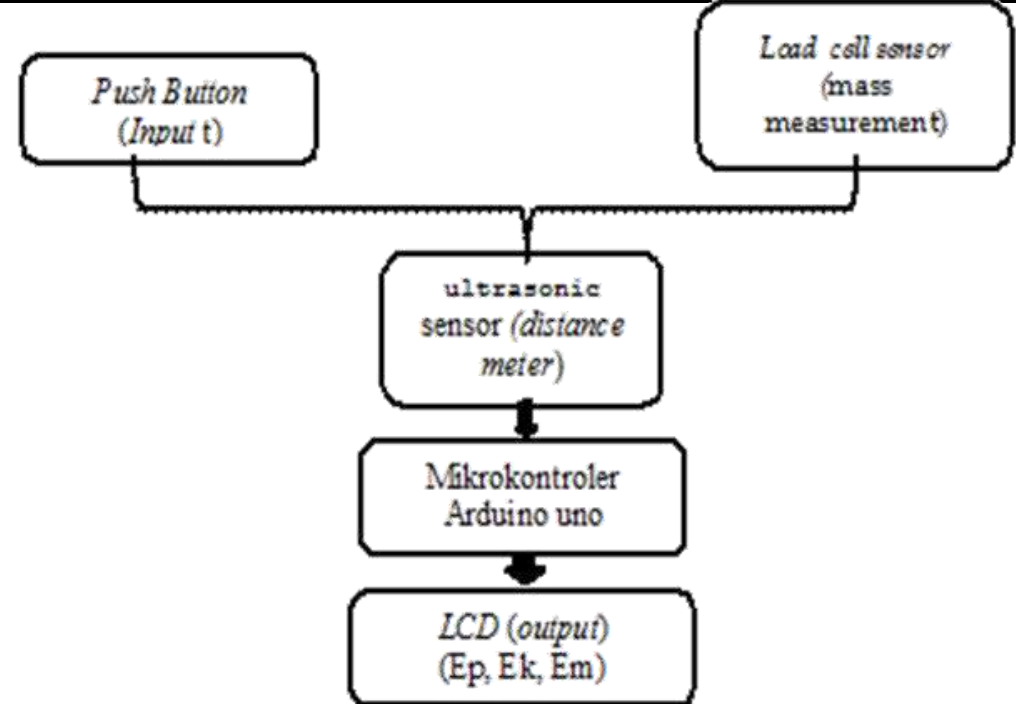

Figure 2. Block diagram of mechanical energy aids.

performance of the hardware made. The design software used is Arduino which controls the entire system.

The flowchart of the experimental set of harmonic motions on a pendulum can be seen in Figure 3. Figure 3 explains that when the mass and height of the object have been inputted, an Arduino component is needed to look for additional variables such

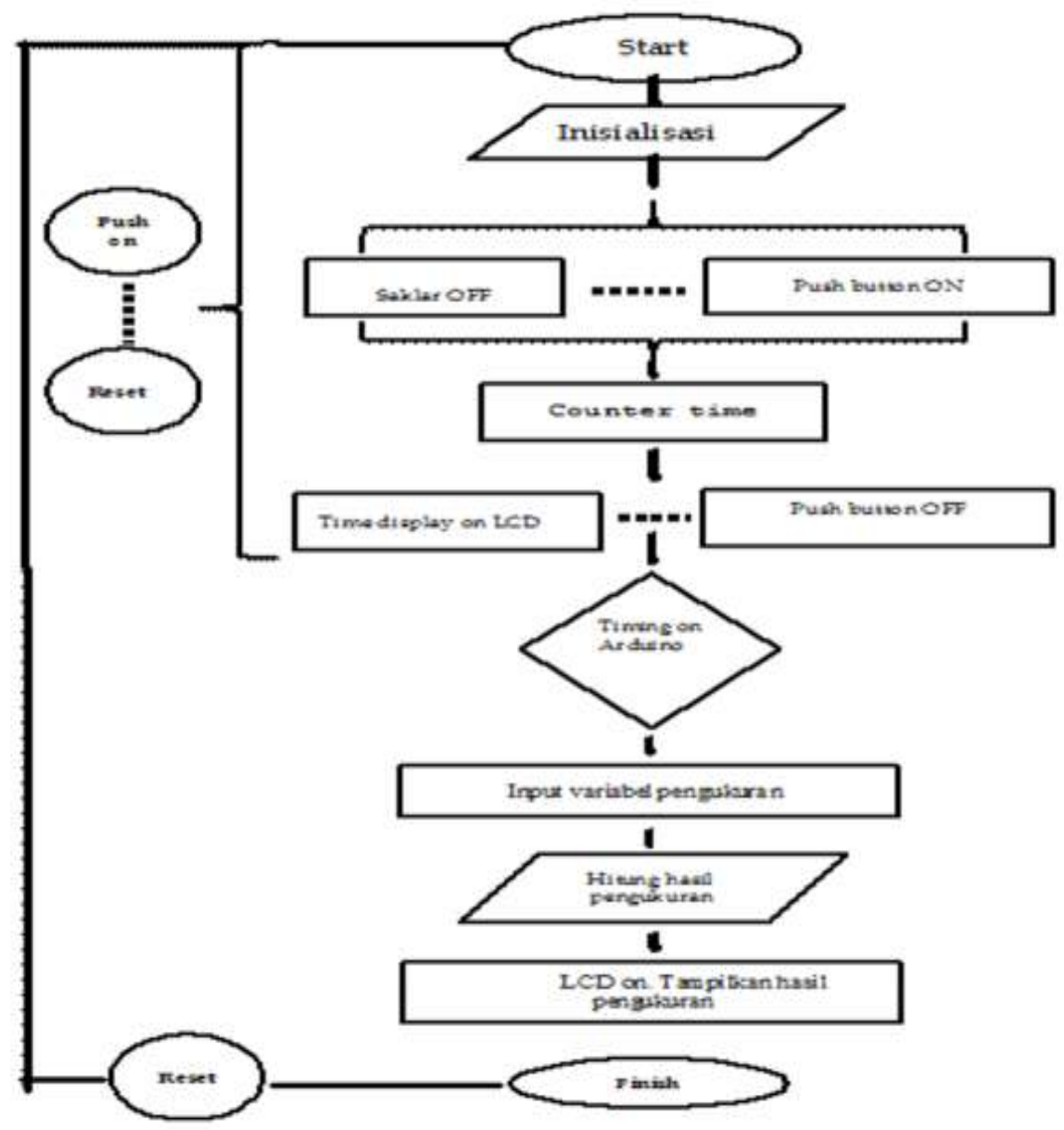

Figure 3. The flowchart of work mechanical energy teaching aids 
as time and object speed. To measure the time of falling objects, 2 push buttons are used with the initialization of start and stop functions. Push-button is used to calculate the time of objects that fall at a certain height. The use of the push button has been initialized in the Arduino program so that when it is pressed simultaneously with a falling object, the time will start reading the object as it falls. If it is on the ground, then quickly and precisely press the push button with the stop function.

When the time of the object has been recorded, then calculate the speed of the object with the equation

$$
v=g \times t
$$

With $g$ as the acceleration of gravity of the earth $\left(9.8 \mathrm{~m} / \mathrm{s}^{\wedge} 2\right)$.

To calculate the mechanical energy of an object, conceptually the equation used is

$$
E M=E P+E K
$$

Meaning that the amount of mechanical energy of an object depends on the sum of its potential energy and kinetic energy. Variables that have been inputted into the Arduino system such as mass, altitude, time, velocity, and gravity, will be used to calculate the potential and kinetic energy of objects and then generate mechanical energy. All variables that have been inputted into the Arduino system will be displayed on the LCD as the Arduino system screen.

The feasibility of the product with a feasibility assessment of the props is carried out. The feasibility test is carried out by media and material experts. The data analysis test used a Likert scale questionnaire to determine the criteria for the teaching aids after the assessment (Damayanti et al., 2018). The criteria used can be seen in Table 1 below.

Table 1. Qualitative criteria for assessment of media experts and experts

\begin{tabular}{ll}
\hline Description & Score \\
\hline Very eligible & $80 \%<P \leq 100 \%$ \\
Eligible & $60 \%<P \leq 80 \%$ \\
Enough & $40 \%<P \leq 60 \%$ \\
Less eligible & $20 \%<P \leq 40 \%$ \\
Not eligible & $0 \%<P \leq 20 \%$ \\
\hline
\end{tabular}

After the product feasibility test is carried out and declared feasible to use, the next stage is a limited trial of the tool to students. The trial was conducted at SMA Negeri 3 Sungai Kakap. The analysis test used a Likert scale questionnaire to determine the criteria for the teaching aids after being tested. The criteria used can be seen in Table 2 below.

Table 2. Criteria for assessment of student response questionnaires

\begin{tabular}{ll}
\hline Description & Score \\
\hline Very good & $80 \%<P \leq 100 \%$ \\
Good & $60 \%<P \leq 80 \%$ \\
Enough & $40 \%<P \leq 60 \%$ \\
Low & $20 \%<P \leq 40 \%$ \\
Very low & $0 \%<P \leq 20 \%$ \\
\hline
\end{tabular}




\section{Result and Discussion}

This study aims to produce a teaching aid that can be used in the physics learning process. In the development process, the ADDIE research model is used which consists of 5 steps, namely: analysis, design, developt, Implementation and Evaluation. However, in its implementation, it only reached the development stage due to limited manpower, time and cost so that the researchers were only limited to testing the feasibility level of the product or props made based on validation by media, material, and student responses without disseminating the product. The following is an explanation of the results of the steps that have been carried out.

\section{Analysis}

This research begins with the analysis stage, which at this stage there are several stages, including problem analysis, material analysis, and research model analysis. In analyzing the problem, the researcher made observations, interviewed physics subject teachers, and interviewed students to find out potential problems in the physics learning process carried out. The results of interviews and observations made found obstacles that occurred in the learning process. These obstacles include the physics learning process that is carried out still using conventional learning methods, namely media-assisted lectures in the form of power points and textbooks that are still not able to attract interest and increase student learning motivation. The use of learning media in the form of teaching aids is not carried out due to the limitations of teaching aids in the laboratory. This research begins with the analysis stage, which at this stage there are several stages, including problem analysis, material analysis, and research model analysis. In analyzing the problem, the researcher made observations, interviewed physics subject teachers, and interviewed students to find out potential problems in the physics learning process carried out.

The results of interviews and observations made found obstacles that occurred in the learning process. These obstacles include the physics learning process that is carried out still using conventional learning methods, namely media-assisted lectures in the form of power points and textbooks that are still not able to attract interest and increase student learning motivation. The use of learning media in the form of teaching aids is not carried out due to the limitations of teaching aids in the laboratory. The involvement of students to be active in the learning process is also less due to minimal use of learning media that is interactive and fun for students such as the use of teaching aids. for students, such as the use of props.

Constraints such as students' difficulties in understanding the concepts of abstract physics are also one of the problems in the physics learning process. This factor is because the learning model is dominated by the delivery of theoretical explanations without demonstrating the physics concepts that occur. The learning that is carried out does not use teaching aids as a medium learning to prove the material concept. The use of teaching aids is still limited to certain materials with minimal amounts plus the props used are conventional with old tools so that they have the potential to be damaged. The measurement of teaching aids is still using manual calculations and there has never been an innovation in control technology-based teaching aids to attract the props used, such as the use of the Arduino Uno microcontroller as one of the innovations in technology-based physics learning teaching aids. 
Analysis of the material is done by looking at the learning outcomes as well as exposure to interviews with physics teachers and students concerning potential problems in the subject matter carried out in the learning process. Data from interviews showed that student learning outcomes about effort and energy, the average student test scores were below the minimum completeness criteria, namely 70. These results can be seen in Table 1 as explained in detail in the introduction.

Judging from the results of the teacher's presentation, it was said that students had difficulty understanding abstract physics concepts such as the concept of potential energy, kinetic energy, and parabolic motion. The results of the analysis of the material carried out concluded that the researcher chose the subject of mechanical energy as the topic of study because the material concept was theoretically produced from the sum of potential energy and kinetic energy by results of interviews that had been conducted the use of teaching aids on potential and kinetic energy material was also needed. Combining the two materials, researchers put together one theoretical concept, namely mechanical energy. The material is also a requirement related to events in everyday life so that direct practical contact is needed in learning so that there is a need for alternative learning media in the form of simple teaching aids containing digital technology visualization of the actual concept but can help students understand the concept of the material, especially students. Can be skilled in using physics learning media based on the use of control technology using Arduino Uno with the help of sensors, provide an attraction for teaching aids, can also attract students' interest, and increase students' motivation to learn physics using teaching aids.

Analysis was also carried out in determining the research model used in the development of teaching aids. The research model used must be following the topic of development studies to produce a valid and effective product to overcome the problems as described. The results of the analysis of the research model, in this research the model used, is the ADDIE research model. The use of this model is based on the topic of development studies, namely the development of physics learning media in the form of teaching aids. Research conducted by Pribadi (2015), the use of the ADDIE research model is suitable for use in this study because the basis for implementing the model is oriented to product development such as learning media in the form of teaching aids.

Design

In this stage, the researcher carried out several activities to produce a valid and effective development product for use. The activities carried out in this stage are as follows:

Minimum system design and manufacturing

The initial stage before making a minimum system of teaching aids as a circuit control system is starting with the manufacture of a system circuit. Making the circuit aims to determine the location of the system to be made. Besides being used to determine the layout of components, the system circuit also has the advantage of reducing excessive budget costs. After making the schematic, the next step is to solder the components according to a predetermined layout so that the components are well connected 


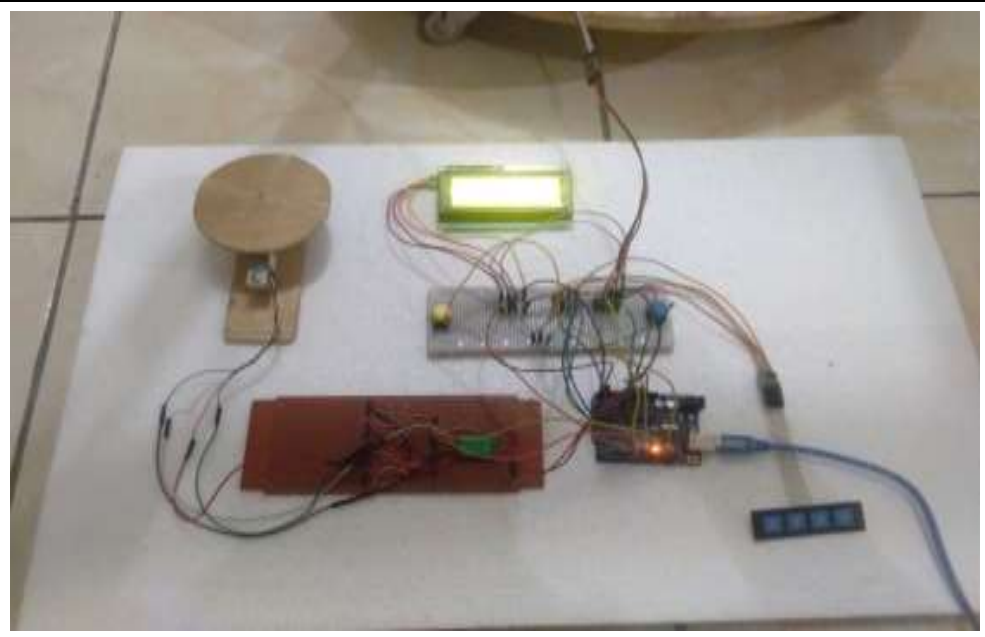

Figure 4. Minimum system design and manufacturing making body or chasing.

The manufacture of chasing props begins with designing the shape and size of the tool that is used as a reference for making the tool. In the manufacture of tool casings using the basic material of $2 \mathrm{~cm}$ iron, the selection of this material is because iron has fairly good resistance to weather which is relatively high compared to materials such as wood so that the tools made can last a long time. The chassis of the tool that has been made is shown in Figure 4. After making the case, the next step is assembling and soldering the necessary components such as Arduino, load cell sensors, ultrasonic sensors, pushbuttons, and jumper cables, and other components. Manufacture of Teaching Aid System Hardware

The manufacture of visual aids hardware has a control system that functions to process Arduino IC data which contains a program system to access data from ultrasonic sensor readings and load cell sensors which are used to calculate the height and mass of an object. The sensor will be given an order by Arduino to calculate the height and mass of the object automatically, the output or value of the sensor reading will be displayed on the LCD. In addition, Arduino will also receive an incoming signal from the push button which functions to input data for the quantity variables used in measuring object time. Strengthening the function of each component uses an Arduino input signal that gets a voltage of $5 \mathrm{~V}$ so that the work functions of the

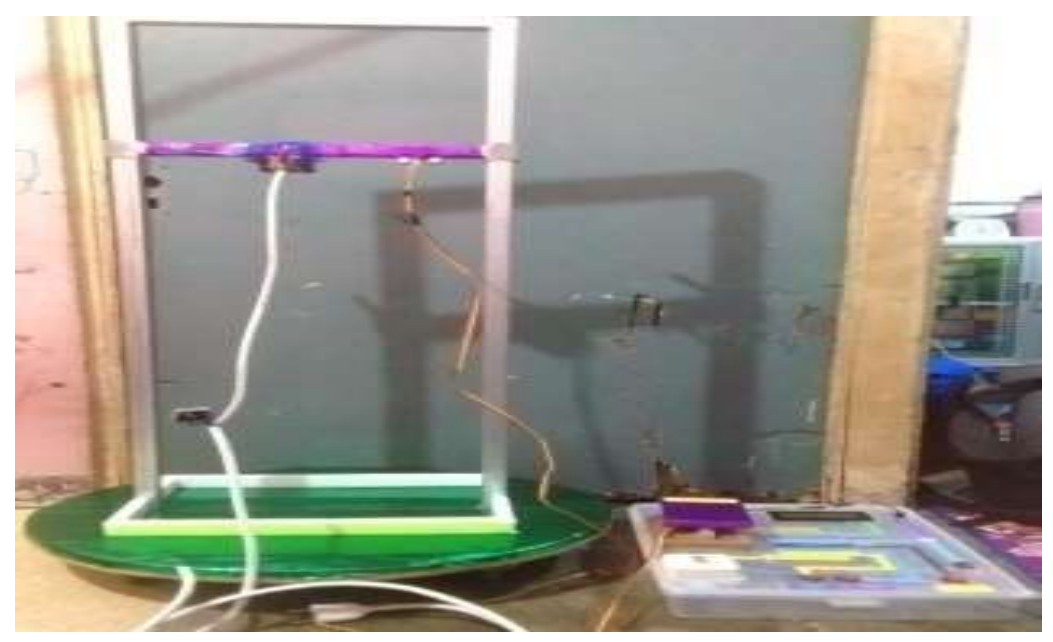

Figure 5. The shape of the chasing props 


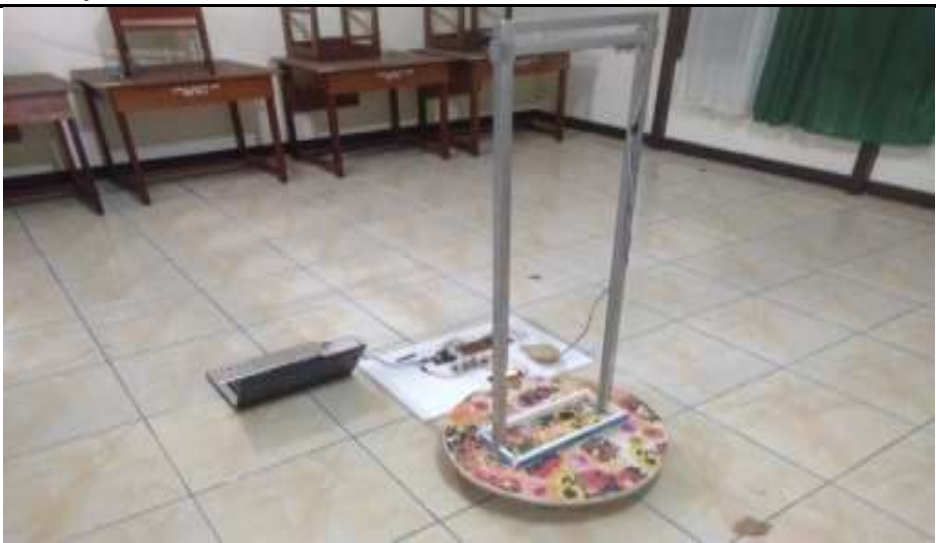

Figure 6. The form of the teaching aid hardware system

components run optimally so that the data reading by the Arduino system can run smoothly and the reading results are also accurate.

Development of props system software

The design of the teaching aid software in this study was carried out by programming the Arduino system. This programming is carried out to regulate the main function of the teaching aid as a counter to the mechanical energy value of objects resulting from ultrasonic sensor measurements and load cell sensors along with other variables assisted by push buttons as buttons that function to input variable data needed in these measurements. The software created is used to activate the work function of the ultrasonic sensor as an object height measurement and load cell sensor as an object mass measurement and push button as an input button in the Arduino system. Arduino software will process the results of altitude measurements.

At this stage, the activity carried out is to test the feasibility of teaching aids. The feasibility test is carried out by validators of media experts and material experts. For media experts, the aspects tested consist of 6 aspects of assessment, namely aspects of resilience, aspects of data presentation, speed of the tool software system in reading
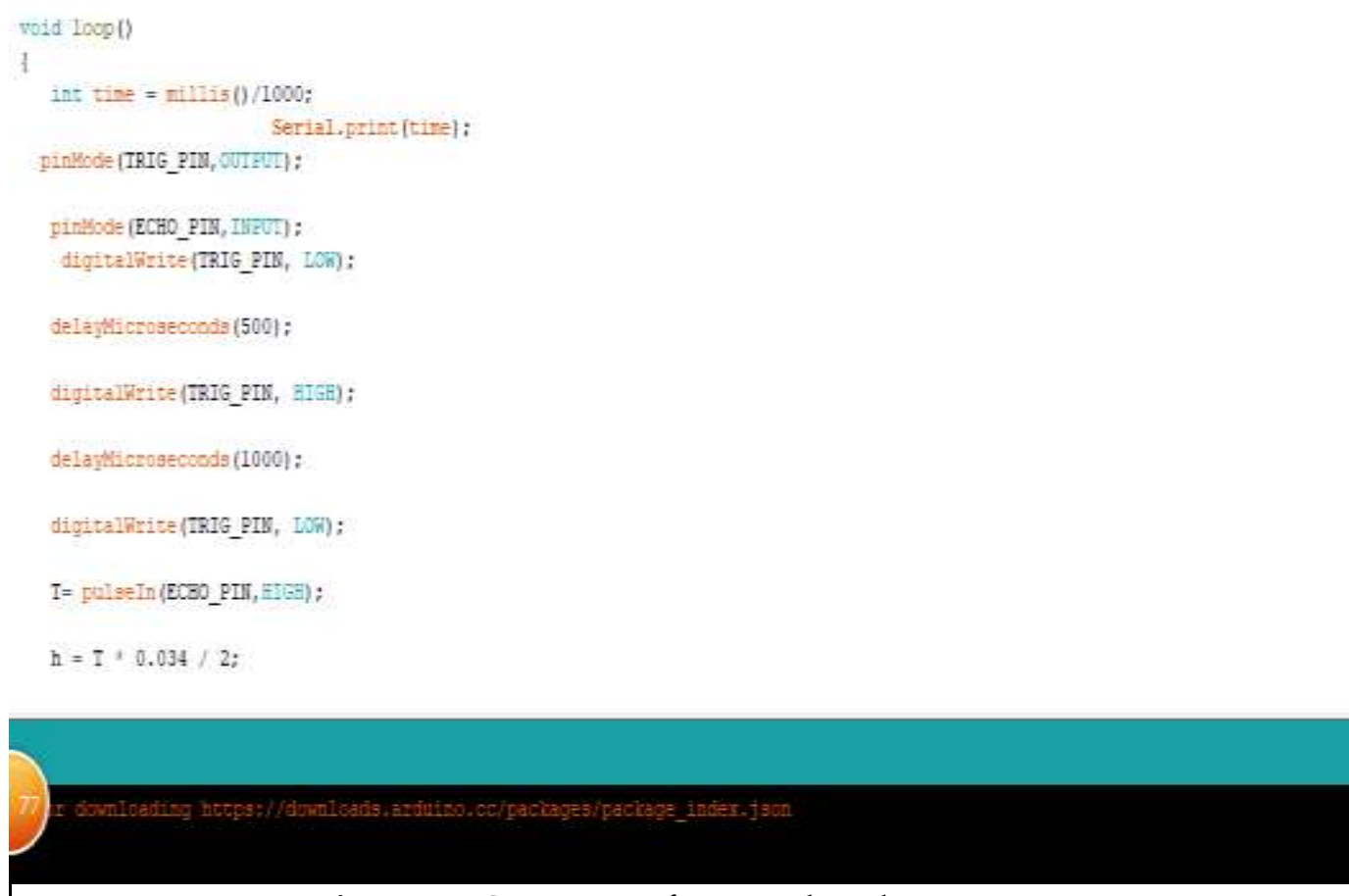

Figure 7. System software development 
Matsun, et.al / Jambura Physics Journal (2021) Vol. 3(2): 135-148

measurement results, tool efficiency, aesthetics, and aspects of physical appearance (tool shape). The results of the media expert's assessment based on these 6 aspects can be seen in Table 3.

Table 3. Obtaining aspects of the media validation sheet

\begin{tabular}{llll}
\hline No. & Aspect & Persentage & Criteria \\
\hline 1 & The tool Resistance & $97,5 \%$ & Very eligible \\
2 & Data Presentation & $90 \%$ & Very eligible \\
3 & $\begin{array}{l}\text { The software system speed } \\
\text { to reading the measurement }\end{array}$ & $100 \%$ & Very eligible \\
& results & & \\
4 & Efisiensi & $93,3 \%$ & Very eligible \\
5 & Estetika & $96,7 \%$ & Very eligible \\
$6 \quad$ tool view & $92,5 \%$ & Very eligible \\
\hline \multicolumn{2}{l}{ Total } & $\mathbf{5 7 0} \%$ & \\
Average & $\mathbf{9 5 \%}$ & Very eligible \\
\hline
\end{tabular}

Table 3 shows the results of the assessment of the feasibility of teaching aids by media expert validators. Based on the calculation results obtained an average percentage score of $95 \%$ with very feasible criteria. The results of these criteria are in line with research conducted by Adi, (2017), based on the media feasibility test conducted on teaching aids, a score of $84.17 \%$ was obtained with very decent criteria. Then based on research conducted by Sari (2019), the results of the media feasibility test carried out on teaching aids obtained a score of $88.34 \%$ with very decent criteria. Based on these results indicate that in the media aspect, the props developed are feasible to use.

For material experts, the aspects tested consist of 3 aspects of assessment, namely aspects of relevance to teaching materials, aspects of educational values, and aspects of implementation. The results of the material expert's assessment based on these 3 aspects can be seen in Table 4 .

Table 4. Obtaining aspects of the material validation sheet

\begin{tabular}{llll}
\hline No. & Aaspect & Persentage & Criteria \\
\hline 1 & In accordance with & $91,65 \%$ & Very eligible \\
& teaching materials & & \\
2 & Educational value & $100 \%$ & Very eligible \\
3 & Execution & $100 \%$ & Very eligible \\
\hline Total & $\mathbf{2 9 1 , 6 5 \%}$ & \\
Average & $\mathbf{9 7 , 2 1 \%}$ & Very eligible \\
\hline
\end{tabular}

Table 4 shows the results of the assessment of the feasibility of teaching aids by material expert validators. Based on the calculation results obtained an average percentage score of $97.21 \%$ with very feasible criteria. The results of these criteria are in line with research conducted by Farasdaq (2019), based on the material feasibility test carried out on teaching aids, a score of $96 \%$ was obtained with very decent criteria.

Based on these results, it shows that in the material aspect, the teaching aids developed are suitable for use in the learning process. After the validation test was carried out by media experts and material experts on the props and was declared 
suitable for use, the next stage was a limited trial to students to find out the response of the props being tested. The student response test consists of 3 main aspects of the assessment substance, namely aspects of learning motivation and understanding of the concept of mechanical energy with teaching aids as a medium, aspects of the operation and performance of teaching aids, and aspects of the quality of teaching aids. The results of the student response test assessment based on these 3 aspects can be seen in Table 5 .

Table 5. Obtaining student response aspects

\begin{tabular}{llll}
\hline No. & Aspect & Persentage & Criteria \\
\hline $1 \quad$ & $\begin{array}{l}\text { Motivation learning and } \\
\text { concept understanding of } \\
\text { mechanical energy with } \\
\text { teaching aids as a medium } \\
\text { for learning physics }\end{array}$ & $90,66 \%$ & Very eligible \\
$2 \quad \begin{array}{l}\text { Operation and performance } \\
\text { of props }\end{array}$ & $87 \%$ & Very good \\
$3 \quad$ Props quality & $85,5 \%$ & Very goog \\
\hline Total & $\mathbf{2 6 3 , 1 6 \%}$ & \\
Average & $\mathbf{8 7 , 7 2 \%}$ & Very good \\
\hline
\end{tabular}

Table 5 shows the results of the assessment of student responses to the use of the developed teaching aids. Based on the calculation results obtained an average percentage score of $87.72 \%$ with very good criteria. The results of these criteria are in line with research conducted by Permatasari (2019), based on student response tests conducted on teaching aids, a score of $85 \%$ was obtained with very good criteria. Then based on research conducted by Masyruhan, et al (2020), based on the response test conducted on teaching aids, a score of $81 \%$ was obtained with very good criteria. Based on these results indicate that in general, the teaching aids developed are suitable for use in the learning process.

\section{Conclusion}

Based on the results of the feasibility test by media experts and material experts as well as student response tests, this research has produced a teaching aid for physics learning based on the Arduino Uno microcontroller. The results of the media feasibility test get an average percentage score of $95 \%$ with very eligible criteria by media experts. For the feasibility of the material on the teaching aids, it gets an average percentage score of $97.21 \%$ with very eligible criteria by material experts. In the aspect of the student response test to the use of teaching aids, the average percentage score of $87.72 \%$ with very good criteria. Based on the results of the data above, overall, the Arduino Uno-based physics learning aids that have been developed are declared valid and suitable for use in the physics learning process.

\section{Acknowledgment}

Special thanks to BRIN which has funded this activity through the 2021 Insinas grant. We also thank the IKIP PGRI Pontianak for providing support and facilities in this research. 


\section{References}

ADI, N. S. (2017). Pengembangan Alat Peraga Gerak Jatuh Bebas Sebagai Penunjang Kegiatan Pembelajaran Fisika Materi Gerak Jatuh Bebas. Inovasi Pendidikan Fisika, 6(2), 23-26 DOI: https://doi.org/10.26740/ipf.v6n2

Alarifin, D. H. (2014). Penerapan Permainan Dalam Pembelajaran Pada Mata Kuliah Fisika Permainan Untuk Menghilangkan Kesan Kaku Calon Guru Fisika. Jurnal Pendidikan Fisika, 2(2). 22-26 DOI : 10.24127/jpf.v2i2.120

Aminulloh, A. M., \& Widodo, W. 2018. Keefektifan Alat Peraga Bunyi untuk Meningkatkan Motivasi Belajar dan Pemahaman Konsep Siswa. PENSA EJURNAL: PENDIDIKAN SAINS, 6(02).

Anas, M. 2014. Alat Peraga dan Media Pembelajaran. Jakarta: Pustaka Education.

Damayanti, A. E., Syafei, I., Komikesari, H., \& Rahayu, R. (2018). Kelayakan Media Pembelajaran Fisika Berupa Buku Saku Android pada Materi Fluida Statis. Indonesian Journal of Science and Matematics Education, 1(1), 63-70 DOI: 10.24042/ijsme.v1i1.2476

Farasdaq, M. H. (2019). Pengembangan Alat Peraga Bandul Matematis Berbasis Mikrokontroler Arduino Untuk Melatih Keterampilan Proses Sains Siswa SMA. In Thesis. FITK UIN Syarif Hidayatullah Jakarta.

Masyruhan, M., Pratiwi, U., \& Al Hakim, Y. 2020. Perancangan Alat Peraga Hukum Hooke Berbasis Mikrokontroler Arduino Sebagai Media Pembelajaran Fisika. Spektra: Jurnal Kajian Pendidikan Sains, 6(2), 134-145 DOI: http://dx.doi.org/10.32699/spektra.v6i2.145

Nurjanah, S., Hakim, Y. A., \& Kurniawan, E. S. (2017). Pengembangan Alat Peraga Kalor Jenis pada Pokok Bahasan Suhu Dan Kalor Berbasis Arduino. Radiasi: Jurnal Berkala Pendidikan Fisika, 10(1), 11-17. DOI: https://doi.org/10.37729/radiasi.v10i1

Pambudi \& Bayu. (2018). Pengembangan Alat Peraga IPA dari Barang Bekas untuk Meningkatkan Motivasi Belajar dan Pemahaman Siswa Sekolah Dasar. Indonesian Journal of Primary Education, 2018, 2.2: 28-33. DOI: https://doi.org/10.17509/ijpe.v2i2.15097

Permatasari, A. (2019). Pengembangan Alat Peraga Lampu Sensor Berbasis Arduino Uno Pada Materi Energi. In Dissertation, UIN Raden Intan Lampung.

Pribadi, B. A. 2015. Desain dan Pengembangan Program Pelatihan Berbasis Kompetensi: Impelemntasi Model ADDIE. Jakarta: Prenada Media Group

Saputri, Y., Al Hakim, Y., \& Fatmaryanti, S. D. (2017). Pengembangan Alat Pengukur Energi Mekanik Pada Pokok Bahasan Usaha Dan Energi Berbasis Mikrokontroler Arduino Uno Untuk Meningkatkan Aspek Psikomotorik 
Siswa. Radiasi: Jurnal Berkala Pendidikan Fisika, 10(1), 29-34. DOI: https://doi.org/10.37729/radiasi.v10i1

Sari, N. A. (2019). Pengembangan Alat Percobaan Tumbukan Sebagai Penunjang Pembelajaran Fisika Materi Momentum Untuk Melatihkan Keterampilan Proses Sains. Inovasi Pendidikan Fisika, 8(2). 722-726.

Sugiyono. (2016). Metode Penelitian Kuantitatif, Kualitatif dan RED. Bandung: Alfabeta.

Syahwil, M. (2013). Panduan Mudah Simulasi dan Praktik. Mikrokontroler Arduino. Yogyakarta: Andi Publisher

Wahyuningsih, F. T., Al Hakim, Y., \& Ashari, A. 2019. Pengembangan Alat Peraga Pengukur Debit Air Menggunakan Sensor Flow Berbasis Arduino Sebagai Media Pembelajaran Fluida. RADIASI: Jurnal Berkala Pendidikan Fisika, 12(1), 38-45. DOI: https://doi.org/10.37729/radiasi.v12i1.31 